\title{
Muhammadiyah dan Spirit Islam Berkemajuan dalam Sinaran Etos Alqur'an
}

\section{ZAKIYUDDIN BAIDHAWY}

Institut Agama Islam Negeri Salatiga

Email: zbaidhawy@gmail.com

\section{ABSTRACT}

Muhammadiyah, one of the largest Islamic movement, has gone beyond a century, and it remains continuously in upholding the ideals of establishing "the truly Islamic society". What is the Muhammadiyah spirit of sustainability in addressing the challenges of the times? Through library approach, this study finds that the Muhammadiyah movement always loyal to and take inspiration from the three ethos of the Quran in achieving the goal of building a truly Islamic society, those are the ethos of rahmah (compassion), al-Ma'un and al ' Ashr. That ethos has been always established on integrative-interconnective approach between the interpretation of the Quran, the sacred heart-mind and the findings of science and technology, and the universal experience of humanity. Rationality is a key of developing the sacred heart-mind capabilities, in addition to experiencing of many nationalities and faiths. From here we know about how to save the lives of people in the world based on the ethos of rahmah. Human happiness is consisting of sincerity, remembering to death, and put science as the key to progress together. Muhammadiyah is also identical with the ethos of al-Ma ${ }^{\prime} u n$, the religious worth of social praxis. Religiosity tends to reject the formalities of religion for it has been included in the social alignments to advocate the weaks. Al- Ashr ethos means that religion (iman) and civilization ('amal shalih) are placed as two separate entities and should be achieved separately. Religion as symbolic formalities is to be important here. Civilization is built through a process of "learning and experiment" and persistency to defeat yourself. Last but not least, Muhammadiyah is no longer overly concerned with the poverty issue, but also regarded to the effective systems and institutions under the effective leadership in building alhadarah al-fadhilah.

Keywords: Islam Berkemajuan, Civilized Muslim,Transformative social-cultural change 


\section{ABSTRAK}

Muhammadiyah, salah satu gerakan Islam terbesar, telah melampaui satu abad, dan tetap terus menjunjung cita-cita untuk membangun "masyarakat Islam yang sebenar-benarnya”. Bagaimanakah semangat keberlanjutan Muhammadiyah dalam menghadapi tantangan zaman? Melalui pendekatan perpustakaan, studi ini menemukan bahwa gerakan Muhammadiyah selalu setia dan mendapat inspirasi dari tiga etos Alquran dalam mencapai tujuan membangun masyarakat Islam yang sesungguhnya, yaitu etos rahmat (welas asih), al-Ma'un dan al- Ashr. Etos tersebut selalu terbentuk pada pendekatan interpersonal integratif antara interpretasi Alquran, hati suci dan penemuan sains dan teknologi, dan pengalaman universal umat manusia. Rasionalitas adalah kunci untuk mengembangkan kemampuan hati-pikiran suci, selain mengalami banyak kebangsaan dan kepercayaan. Dari sini kita tahu bagaimana cara menyelamatkan nyawa orang di dunia berdasarkan etos rahmah. Kebahagiaan manusia terdiri dari ketulusan, mengingat, dan menjadikan sains sebagai kunci kemajuan bersama. Muhammadiyah juga identik dengan etos al-Ma'un, nilai religius praksis sosial. Religiusitas cenderung menolak formalitas agama karena telah disertakan dalam keberpihakan sosial untuk mengadvokasi penyiksaan. Al-`Ashr etos berarti bahwa agama (iman) dan peradaban ( 'amal shalih) ditempatkan sebagai dua entitas yang terpisah dan harus dicapai secara terpisah. Agama sebagai formalitas simbolik menjadi penting di sini. Peradaban dibangun melalui proses "belajar dan bereksperimen" dan persistensi untuk mengalahkan diri sendiri. Yang terakhir namun tak kalah pentingnya, Muhammadiyah tidak lagi terlalu peduli dengan isu kemiskinan, namun juga menganggap sistem dan institusi efektif di bawah kepemimpinan efektif dalam membangun al-hadarah al-fadhilah.

Kata kunci: Islam Berkemajuan, Muslim berkeadaban, Perubahan social-kultural

\section{PENDAHULUAN}

Perdebatan mengenai perlunya Muhammadiyah mengambil kembali peran sebagai gerakan reformasi model kaum puritan Protestan pernah bergaung. Para penganjur usulan ini sering mensejajarkan sifat-sifat Puritan Calvinis dengan Puritan Muhammadiyah. Biasanya mereka setia merujuk tesis-tesis Weber dan Indonesianis-Weberian, utamanya Clifford Geertz, James L. Peacock. Mitsuo Nakamura, Irwan Abdullah dan sebagainya untuk memperkuat argumentasi. Namun etos Muhammadiyah melampaui dari sekadar bicara tentang hubungan antara aktivitas keagamaan dan aktivitas ekonomi, antara etos dan semangat kapitalisasi. Locus dan tempus yang terus berubah mendorong Muhammadiyah beradaptasi sesuai dengan tantangan dan peluang yang dihadapi. Muhammadiyah terus bergerak dan menggeliat dalam dialektika peradaban.

Basis teologis etos Muhammadiyah dapat diketahui dari pemikiran dan 
aksi-amaliah KH. Ahmad Dahlan. Sejauh ini, di antara murid-murid Kyai Dahlan, hanya KRH. Hadjid dan Kyai Syuja' yang menjadi sumber informasi utama untuk mengetahui pemikiran KH. Ahmad Dahlan. Buku Pelajaran KHA. Dahlan: 7 Falsafah Ajajaran dan 17 Kelompok ayat Alquran karya $\mathrm{KRH}$. Hadjid merupakan sekumpulan informasi pandangan filosofis dan teologis Dahlan. ${ }^{1}$ Begitu juga catatan Kyai Syuja' berjudul Islam Berkemajuan memuat riwayat atau rekam jejak perilaku Kyai Dahlan semasa hidup. ${ }^{2}$ Terdapat beberapa karya tulis Dahlan antara lain Tali Pengikat Hidup Manusia ${ }^{3}$ dari Almanak tahun 1923, dan Peringatan bagi Sekalian Muslimin (Muhammadiyyin) yang disampaikan dalam Kongres Islam Cirebon tahun 1921. Kedua naskah itu, bisa ditemukan dalam lampiran karya Abdul Munir Mulkhan.4

Gagasan dan etos gerakan Kyai Dahlan yang jauh lebih besar adalah sikap terbukanya menyerap puncak-puncak peradaban tanpa memandang bangsa dan agama pengemban peradaban itu. ${ }^{5}$ Karena berbagai aksi sosial yang dikembangkan Kyai Dahlan terisnpirasi dari pengalaman orang-orang asing Kristiani dan warga Belanda, Inggris atau Portugis. Panti Asuhan Yatim Piatu, Panti Jompo, Rumah Sakit, Rumah Miskin ${ }^{6}$ dan Sekolah Modern merupakan hasil dialog peradaban Kyai Dahlan dengan manajemen kehidupan di bidang kesehatan, sosial, dan pendidikan kaum Kristiani dan pejabat Kolonial Belanda. ${ }^{7}$ Karena itu, paper ini berupaya menggali dan mengkaji basis teologis-qur'anik yang menggerakkan etos dan spirit Islam berkemajuan dalam gerakan Muhammadiyah.

\section{TUJUH FALSAFAH DAN 17 KELOMPOK AYAT ALQURAN}

$\mathrm{KRH}$. Hadjid, murid termuda KH Ahmad Dahlan, menulis 7 falsafah ajaran dan 17 kelompok ayat Alquran yang menjadi pokok wejangan dan pelajaran pendiri Persyarikatan Muhammadiyah bagi murid-murid dan pengikutnya. Tujuh falsafah dan tujuhbelas kelompok ayat Alquran tersebut merupakan pegangan utama para pewaris Muhammadiyah yang tidak sedikit diantara mereka telah mematrikan jiwa/ruh berMuhammadiyah dalam kehidupan bermasyarakat dan berbangsa. ${ }^{8}$

Tujuh falsafah ajaran yang dimaksud ialah; 1) manusia hidup di dunia hanya sekali untuk bertaruh; sesudah mati, akan mendapat kebahagiaankah atau kesengsaraan; 2) Kebanyakan di antara manusia berwatak angkuh dan takabbur, mereka mengambil keputusan sendiri-sendiri; 3) Manusia itu kalau mengerjakan pekerjaan apapun, sekali, dua kali, beru- 
lang-ulang, maka kemudian jadi biasa. Kalau sudah menjadi kesenangan yang dicintai, maka kebiasaan yang dicintai itu sukar untuk diubah. Sudah menjadi tabiat bahwa kebanyakan manusia membela adat kebiasaan yang telah diterima, baik itu dari sudut keyakinan atau i'tikad, perasaan kehendak maupun amal perbuatan. Kalau ada yang akan mengubah, mereka akan sanggup membela dengan mengorbankan jiwa raga. Demikian itu karena anggapannya bahwa apa yang dimiliki adalah benar; 4) manusia perlu digolongkan menjadi satu dalam kebenaran, harus bersama-sama menggunakan akal fikirannya untuk memikirkan bagaimana sebenarnya hakikat dan tujuan manusia hidup di dunia. Apakah perlunya? Hidup di dunia harus mengerjakan apa? Dan mencari apa? Dan apa yang dituju? Manusia harus mempergunakan pikirannya untuk mengoreksi soal i'tikad dan kepercayaannya, tujuan hidup dan tingkah lakunya, mencari kebenaran sejati. Karena kalau hidup di dunia hanya sekali ini sampai sesat, akibatnya akan celaka dan sengsara selama-lamanya."Adakah engkau menyangka bahwasannya kebanyakan manusia suka mendengarkan atau memikirmikir mencari ilmu yang benar" (QS. al-Furqan: 44); 5). Setelah manusia mendengarkan pelajaran-pelajaran fatwa yang bermacam-macam, membaca beberapa tumpuk buku..., Sekarang, kebiasaan manusia tidak berani memegang teguh pendirian dan perbuatan yang benar karena khawatir kalau menetapi kebenaran akan terpisah dari apa-apa yang sudah menjadi kesenangannya, khawatir akan terpisah dari teman-temannya. Pendek kata, banyak kekhawatiran itu yang akhirnya tidak berani mengerjakan barang yang benar, kemudian hidupnya seperti makhluk yang tak berakal, hidup asal hidup, tidak menempati kebenaran; 6) Kebanyakan pemimpin-pemimpin rakyat, belum berani mengorbankan harta benda dan jiwanya untuk berusaha tergolongnya umat manusia dalam kebenaran. Malah pemimpin-pemimpin itu biasanya hanya mempermainkan, memperalat manusia yang bodoh-bodoh dan lemah; 7) Pelajaran terbagi atas dua bagian: belajar ilmu, pengetahuan atau teori dan belajar amal, mengerjakan atau mempraktikkan. Semua pelajaran harus dengan cara sedikit demi sedikit, setingkat demi setingkat...Demikian juga dalam belajar amal, harus bertingkat. Kalau setingkat saja belum dapat mengerjakan, tidak perlu ditambah.

Adapun 17 kelompok ayat Alquran yang menjadi pokok wejangan dan pelajaran dari pendiri Persyarikatan Muhammadiyah adalah sebagai berikut: 1) Membersihkan diri sendiri, Al-Jathiyah ayat 23; 2) Menggempur 
hawa nafsu mencintai harta benda, al-Fajr ayat 17-23;(3) Orang yang mendustakan agama, al-Ma'un ayat 1-7; 4) Apakah artinya agama itu, alRum ayat 30; 5) Islam dan sosialisme, al-Tawbah ayat 34-35; 6) Surat al'Ashr ayat 1-3; 7) Iman/kepercayaan, al-'Ankabut ayat 1-3; 8) Amal sholeh, al-Kahf ayat 110 dan al-Zumar ayat 2; 9) Wa tawashaw bil haqq, Yunus ayat 108, al-Kahf ayat 29, Muhammad ayat 3, al-An'am ayat 116, alFurqan ayat 44, al-Anbiya' ayat 24, Yunus ayat 32, al-Shaff ayat 9, alBaqarah ayat 147, al-Anfal ayat 8, al-Isra' ayat 81 dan al-Mu'minun ayat 70; 10) Wa tawashaw bi al-shabri; 11) Jihad, Ali 'Imran ayat 142; 12) Wa ana minal muslimin, al-An'am ayat 162-163; 13) Al-Birru, Ali 'Imran ayat 92 ; 14) Surat al-Qari'ah ayat 6-11; 15) Surat al-Shaff ayat 2-3; 16) Menjaga diri, al-Tahrim ayat 6; dan terakhir 17) Apakah belum waktunya, surat alHadid ayat 16.

Demikianlah tujuh falsafah ajaran dan tujuh belas kelompok ayat Alquran yang selalu ditekankan oleh KH.Ahmad Dahlan kepada muridmuridnya. Kalau kita amati dengan cermat, terdapat tiga tahapan kerangka etos Muhammadiyah (Kyai Dahlan) dalam semangat pembangunan peradaban. Sebagaimana pesan Kyai, "pengetahuan tertinggi" adalah pengetahuan tentang kesatuan hidup. Pengetahuan tersebut dapat dicapai dengan sikap kritis dan terbuka dengan menggunakan akal sehat dan istiqamah terhadap kebenaran akali dengan didasari hati suci."9 Pesan tersebut mengandung tiga etos dalam mencapai"peradaban utama" (pengetahuan tertinggi), yaitu etos welas asih (hati suci), etos al-ma'un (sikap kritis dan terbuka) serta etos al- 'ashr (pengetahuan tentang kesatuan hidup).

Gagasan dasar Ahmad Dahlan terletak pada "kesejajaran kebenaran" (integrasi-interkoneksi) tafsir Alquran (hadharah al-Nas), akal suci dan temuan iptek (hadharah al-'ilm), dan ketiga, pengalaman universal kemanusiaan (hadharah al-falsafah). Belajar filsafat baginya adalah kunci pengembangan kemampuan akal suci, selain belajar pada pengalaman beragam bangsa dan pemeluk agama. Dari sini diperoleh pengetahuan, yaitu penyelamatan kehidupan umat manusia di dunia berdasarkan etos cinta kasih (belas asih/welas asih). Kebahagiaan itu adalah "sikap ikhlas, tidak lupa kematian, dan menempatkan ilmu sebagai kunci kemajuan dan kebahagiaan bersama".

\section{ETOS WELAS ASIH}

Etos welas asih berdasarkan pandangan bahwa kebenaran dan kebaikan 
Islam terletak pada kegunaan dan manfaat bagi semua orang melampaui batas-batas agama dan bangsa. Asas cinta kasih merupakan dasar bagi gerakan kemanusiaan universal dan pembagunan peradaban Muhammadiyah. Visi pembebasan Muhammadiyah saat itu berhadapan dengan masyarakat Hindia Timur yang mengalami penderitaan akibat kemiskinan, kebodohan, dan kepenyakitan. Dalam dokumen gerakan Muhammadiyah disebutkan situasi ideal yang diharapkan sebagai hasil pencerdasan dan pemberdayaan adalah Islam yang kuat, sehat, besar dan maju. ${ }^{10}$ Orientasi gerakan Muhammadiyah terlihat pada pembelaan kaum tertindas dan pencerdasan seluruh lapisan umat melalui pendidikan (sebagian dengan jalan tabligh) yang dilandasi nilai yang disebut oleh dr. Soetomo sebagai 'cinta kasih' atau disebut Abdul Munir Mulkhan sebagai "etos welas asih". ${ }^{11}$ Semangat kemanusiaan berbasis cinta-kasih telah mempersatukan orangorang yang berbeda bangsa dan agama dalam Muhammadiyah. Kerja sosial Muhammadiyah didasarkan atas pandangan bahwa kebenaran (alhaq) dan kebaikan (al-khair) Islam adalah manfaatnya tanpa memandang batas bangsa dan agama. "Alquran Suci" dipahami dengan "Akal Suci" dan "Hati Suci" serta diamalkan dengan welas asih sebagai etos kemajuan peradaban, keselamatan dunia dan kemanusiaan. ${ }^{12}$

Etos cinta-kasih telah menarik minat seorang elite priayi Jawa, dr. Soetomo. la bersedia menjadi penasehat Muhammadiyah di bidang kesehatan. Bersama dokter Belanda, dr. Soetomo mengelola rumah sakit Muhammadiyah tanpa gaji. ${ }^{13}$ Pengelolaan rumah sakit melibatkan dokterdokter Nasrani Belanda yang bekerja sukarela, sekolah dikelola secara modern guna meningkatkan taraf hidup dan berperan dalam dunia modern. Umat mulai menyadari manfaat bekerja sama dengan semua pihak tanpa melihat agama dan kebangsaan bagi kemajuan dan kesejahteraan

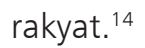

Semangat kemanusiaan berbasis etos welas asih telah mempersatukan orang-orang yang berbeda bangsa dan agama tersebut. ${ }^{15}$ Menurut $d r$. Soetomo, etos welas kasih merupakan kritik atas Darwinisme sebagai paradigma pemikiran Barat modern yang meletakkan seleksi alam atas kekuatan individual. Darwinisme tidak memberikan kekuatan kaum lemah untuk menjadi berkemajuan. ${ }^{16}$ Sebagaimana cuplikan pidato dr. Soetomo dalam upacara peresmian Rumah Sakit PKO Muhammadiyah Surabaya ${ }^{17}$ yang saat itu dr. Soetomo menjabat sebagai Medisch Adviseur H.B. PKO Muhammadiyah. Dalam sambutannya yang berjudul "Cinta Kasih Vs. 
Darwinisme" disampaikan:

"Lagi pula, boleh dikatakan akan timbangan atau perlawan pengajaran Darwin. Bukankah pengajaran Darwin itu berasaskan kepuasan hidup? Sudah tentu saja kejadiannya pengajaran ini menindas dan memusnahkan yang bersifat lembek. Karena bermaksud untuk diri sendiri, supaya dalam dunia ini mendapat tempat yang baik. Sedang pikiran baru itu timbul dari asas lain, yakni asas cinta-kasih. Asas cinta-kasih ini sudah barang tentu tiada mengizinkan, tiada memberi kesempatan, beberapa untuk keperluan diri sendiri. Akan tetapi, mewajibkan berkurban untuk mencapai hidup mulia bagi umum. Dan kalau begitu, apakah yang disebut cinta-kasih pada orang tua, pada istri dan anak atau lainnya? Tiada lain hanyalah mengorbankan diri untuk keselamatan dan kebahagiaan orang lain. Begitu juga perserikatan kami ini kemasukan pikiran cinta-kasih, yang akan kita curahkan kepada sesama manusia, supaya dengan cinta-kasih dan berkorban dapatlah tercapai hidup mulia,... Besuk pagi kita buka poliklinik ini. Siapa juga, baik orang Eropa, baik orang Jawa (orang pribumi), baik Cina atau bangsa Arab, boleh datang kemari, akan ditolong cuma-cuma, asalkan betul miskin. ${ }^{18}$

Agar manusia memperoleh kesempurnaan, ia harus memenuhi antara lain: Pertama, dalam memilih perkara harus dengan belas asih (etika welas asih). Sebab manusia tidak akan sampai pada derajat utama, jika tidak dengan belas kasih. Karena, watak dan sifat orang yang tidak memiliki belas kasih itu segala perbuatannya didasarkan pada kesenangan, yang semakin lama semakin bosan dan lalu menjadi sia-sia. Kedua, bersungguhsungguh dalam mencari, karena sesungguhnya segala sesuatu yang ditujukan kepada keutamaan dunia dan akhirat itu tidak akan tercapai apabila tidak dengan daya upaya, ikhtiar, pengorbanan harta benda, dan dengan kekuatan pikiran.

Dua hal di muka menunjukkan bahwa etos welas asih Kyai Dahlan melampaui etos Protestan, yang berujung pada semangat kapitalisme. Etos welas asih bersandar pada nalar dan moralitas yang mendorong seseorang melakukan dan memperjuangkan sesuatu demi hidup paripurna, jauh dari kesenangan materialistik-hedonistik yang sia-sia dan memperdaya. Etos gerakan Muhammadiyah melukiskan praksis teologi peradaban. Relasirelasi sosial-ekonomi-politik-kultural terjalin melampaui batas-batas keagamaan, etnisitas, dan kebangsaan.Gerakan Muhammadiyah mengelaborasi dan mengeksploitasi "etos welas asih" ini sebagai bagian utama dari misi universal Islam rahmatan lil 'alamin. Pengalaman induktif kema- 
nusiaan universal Kyai Ahmad Dahlan sendiri menjadi dasar bagi hampir seluruh gagasan dan etos gerakannya.

\section{ETOS AL-MA'UN}

Ada kisah berkesan tentang bagaimana KH.Ahmad Dahlan mengajarkan surah al-Ma'un kepada murid-muridnya. la mengajarkan surat ini selama tiga bulan dan tidak mau beranjak ke surat berikutnya, meskipun murid-muridnya sudah mulai bosan. Dihimpit oleh rasa bosan itu, salah seorang muridnya, KH. Syuja' pun bertanya, "Mengapa Kyai Dahlan tidak mau beranjak untuk mempelajari surat selanjutnya?" Lantas Kyai Dahlan balik bertanya, "Apakah kamu benar-benar memahami surat ini?" KH. Syuja' menjawab bahwa ia dan teman-temannya sudah paham betul arti surat tersebut dan menghafalnya di luar kepala. Kemudian Kyai Dahlan bertanya lagi, "Apakah kamu sudah mengamalkannya?" Jawab H. Syuja', "Bukankah kami membaca surat ini berulang kali dalam shalat?"

Kyai Dahlan lalu menjelaskan bahwa maksud mengamalkan surat alMa'un bukan menghafal atau membaca, tetapi lebih penting dari itu adalah melaksanakan pesan surat al-Ma'un dalam bentuk amal nyata. "Oleh karena itu', lanjut Kyai Dahlan, "setiap orang harus keliling kota mencari anak-anak yatim, bawa mereka pulang ke rumah, berikan sabun untuk mandi, pakaian yang pantas, makan dan minum, serta berikan mereka tempat tinggal yang layak. Untuk itu pelajaran ini kita tutup, dan laksanakan apa yang telah saya perintahkan kepada kalian." Cerita di atas menggambarkan bagaimana seharusnya ayat-ayat Alquran dipelajari dan diamalkan, jangan beranjak ke ayat lain sebelum memahami dan mengamalkan pesan ayat tersebut. ${ }^{19}$

Terdapat lima jalan Kyai Ahmad Dahlan dalam memahami Alquran: mengerti artinya; memahami tafsir dan maksudnya; jika mendapat larangan dalam Alquran bertanyalah kepada diri sendiri apakah larangan semacam itu sudah ditinggalkan; jika mendapati amar (perintah) perbuatan dalam Alquran tersebut, bertanyalah kepada diri sendiri apakah amar atau perintah berbuat tersebut sudah diamalkan; jika yang keempat belum diamalkan, jangan membaca ayat lain. ${ }^{20}$ Termasuk dalam kasus pengamalan surat al-Ma'un.

Sulit diketemukan kitab tafsir yang memberi penjelasan maksud surat al-Ma'un seperti pemahaman Kyai Dahlan yang terbaca dari berbagai aksi sosial. Tafsir Kyai Dahlan atas al-Ma'un (barang berguna) itu mendasari 
karya amalnya yang diperuntukkan kepada kaum dhuafa' (proletar, tentindas). ${ }^{21}$ Etos al-Ma'un menjadi referensi aksi pemberdayaan kaum tertindas seperti aksi pemberdayaan perempuan di ruang publik. ${ }^{22}$ Legenda al-Ma'un menempatkan aksi kongkret sebagai tafsir autentik Kitab Suci. ${ }^{23}$

Sukidi dan Robert W. Hefner pernah menulis dalam Bentara Kompas (2 Maret, 6 April, dan 1 Juni 2005) dengan tema 'Protestanisme Islam dan Muhammadiyah'. Namun pendapat mereka dibantah oleh Munir Mulkhan. Menurutnya, penyebutan Muhammadiyah sebagai reformasi Islam model Protestan kurang tepat karena beberapa fakta sosial menunjukkan tidak tumbuhnya akumulasi kapital seperti kehidupan kaum Calvinis. Muhajir Effendi menyebut kaum Muhammadiyin dengan sebutan kaum "al-Ma'unis".

Aksi sosial dan revolusi kebudayaan Ahmad Dahlan didasarkan pandangan tentang kesesuaian natural tafsir Alquran, pengalaman kemanusiaan universal, dan temuan iptek. Baginya ukuran kebenaran tafsir Alquran dan temuan iptek ialah sejumlah bukti kemanfaatannya bagi penyelesaian problem universal kemanusiaan. Munir Mulkhan menyebut semangat dan etos kemanusiaan Dahlan sebagai terapan dari pragmatisme-humanistik, bukan etos Protestanisme.

Etos ini berujung pada spirit peradaban. Ini dapat disaksikan dari semua karya dan amal usaha Muhammadiyah. Berdirinya rumah sakit PKU Muhammadiyah di saentero Nusantara diawali dari sebuah poliklinik yang dipimpin oleh dr. Somowidagdo asli Malang. Poliklinik kecil di Yogyakarta ini, berkembang menjadi gerakan kesehatan yang merupakan pilar gerakan dan pelayanan kesehatan Muhammadiyah selain pendidikan. Pencetus poliklinik ini adalah Majelis PKO (Penolong Kesengsaraan Oemoem) HB (Pimpinan Pusat) Muhammadiyah dibawah Kyai Syuja'. Langkah ini tercantum dalam perencanaan Majelis PKO yang dibentuk pada tahun 1920. Sebelum poliklinik berdiri, dokter Somowidagdo bertemu dengan Kyai Dahlan terlebih dahulu untuk memperoleh ijinnya untuk menangani poliklinik kesehatan pertama milik Muhammadiyah. Saat dikukuhkannya Majelis PKO oleh Kyai Dahlan bersama Majelis Sekolahan, Majelis Tabligh dan Majelis aman Pustaka pada 17 Juni 1920, Kyai Syuja' sebagai Ketua memprogramkan pembangunan hospital (rumah sakit), armenhuis (rumah miskin) dan weeshuis (rumah yatim) sebagai tafsir amali surat al-Ma'un. ${ }^{24}$ 


\section{BERAGAMA PALSU}

Dalam konteks kontemporer etos al-Ma'un di atas tengah diperhadapkan dengan tantangan kehidupan yang lebih rumit dan canggih. Sistem-sistem sosial-ekonomi-politik kini dalam pertarungan sengit antara Libertarianisme dan Keynesianisme terkait dengan soal seberapa besar alam semesta ini memiliki kemampuan untuk menyediakan sumber daya bagi penduduk planet bumi. Konsumsi manusia modern telah menghabiskan kapital alam, baik kapital yang tidak dapat diperbarui (non-renewable capital), seperti bahan bakar minyak fosil, dan kapital yang dapat diperbarui (renewable capital), seperti hutan, perikanan, tanah, air, dan sistem iklim.

Sistem semacam ini tak dapat dimungkiri telah merampas kekayaan dan kekuasaan dari mayoritas ke minoritas; menciptakan konsentrasi kekayaan dan kekuasaan yang terus meningkat, sehingga mendorong gaya hidup extravagan yang mubadzir, boros dan sia-sia pada sebagian kecil orang, dan pada saat yang sama melahirkan deprivasi dan perbudakan bagi bilyunan orang; dan mempercepat kehancuran kekayaan alam yang telah merampas kehidupan bilyunan penduduk bumi. Kecenderungan semacam ini akan menjegal nasib umat manusia jika dibiarkan terus berlanjut.

Gambaran seperti di atas menyerupai, meski dengan representasi yang lebih sederhana, konteks historis turunnya surat al-Ma'un. Sebagaimana trio Bretton Woods (IMF, World bank, WTO), symptom masyarakat Mekkah pra Islam mengenal "trio jahiliyah" - Abu Sufyan, Abu Jahl, dan al- 'Ash Ibn Walid. ${ }^{25}$ Mereka adalah tokoh-tokoh yang memiliki sifat kemaruk harta dan kekayaan dan gemar berfoya-foya secara mencolok di hadapan mayoritas penduduk yang miskin dan serba kekurangan. Mereka juga tidak memiliki kepekaan sama sekali atas ketertindasan kaum papa.

Kutukan sebagai pendusta agama ditujukan kepada individu, kelompok, dan sistem yang apatis dan tidak memiliki solidaritas sosial atas kaum mustadh'afin. Karakteristik yang mudah dikenali pada diri mereka adalah suka menghardik, menakut-nakuti, mengancam, menindas individu, kelompok, masyarakat dan negara "yatim" yang tidak berdaya secara sosial, ekonomi dan politik; mereka juga tidak peduli kepada kemiskinan dan pemiskinan; bahkan mereka sendiri pelaku pemiskinan dan penindasan atau kompradornya; melakukan "pembiaran" (yutm) atas kemiskinan dan pemiskinan; serta tidak berdiri dalam posisi memihak kepada kaum dhuafa.

Hal serupa berlaku bagi kaum agamawan, kaum Muslim yang rajin 
melakukan shalat lima waktu sehari semalam. Shalat mereka tidak menyelamatkan diri mereka sendiri dari api neraka pada hari akhir, karena toh mereka juga tidak berbuat apa-apa, tidak menyelamatkan orang lain yang yatim dan miskin selama hidup di dunia. Ini merupakan sifat "shalat yang mencelakakan" sebagai akibat mereka "lalai, abai" terhadap problem kemiskinan dan penindasan yang kasat mata di hadapan mereka. Kaum agamawan dan para penegak shalat yang celaka adalah juga mereka yang "menghalangi, menghambat" individu, kelompok, atau sistem yang berusaha memberikan bantuan, pertolongan dan pemberdayaan kepada kaum miskin.

Oleh karena itu, perlawanan atas sistem yang rakus dan menindas hanya dapat muncul dari kesadaran keagamaan dan "shalat yang memihak", yakni shalat yang memihak keadilan - hak setiap orang untuk bicara dan hak atas sarana-sarana kehidupan dan penghidupan. Siapa yang berjuang untuk mempertahankan kehidupan dari regim perompak, memberikan bantuan karitas, dan pemberdayaan kapasitas dan otoritas kepada kaum miskin, itulah dia yang "shalatnya menyelamatkan" kemanusiaan, ia mujahid anti-kemiskinan dan pembela kaum miskin; ia juga siap mati syahid dalam membela hak-hak kaum miskin dari para begundal kapitalisneoliberalis dan kaki tangannya yang "jahil murakab" (triple idiots).

\section{SPIRIT KEUNTUNGAN UNTUK KEBAJIKAN}

Visi keberpihakan terhadap kaum dhuafa dan mustadh'afin sebagaimana tersurat dalam etos al-Ma'un berhubungan erat dengan al-Takathur. Pertama, karena surat al-Ma'un itu sendiri secara kronologis turun sesudah surat al-Takathur. Kedua, secara substantif ada kesamaan pesan yang menegaskan larangan bersikap dan bertindak "abai, lalai, dan lengah, leha-leha" dalam hal kapital dan kepedulian terhadap sesama yang membutuhkan.

Al-Takathur sendiri secara harfiah bermakna "menumpuk, memperbanyak, menimbun" sesuatu. Secara maknawi mengandung beberapa hal antara lain: al-takathur secara alamiah merupakan sifat manusiawi oleh karena setiap individu memiliki kecenderungan untuk menumpuk harta/ kekayaan sebanyak-banyaknya; secara hukum, menumpuk harta dan kekayaan adalah diperkenankan, karena dianjurkan agar setiap orang berkecukupan secara ekonomi untuk memenuhi kebutuhan dan keinginannya, dan tidak meminta-minta; al-takathur secara sistem merupakan 
aktivitas "kapitalisasi" melalui proses dan prosedur yang berlaku dan terjaga keadilannya. Ketika prasyarat ketiga ini tidak terpenuhi, maka al-takathur telah menjerumuskan diri pada regim "kapitalisme", yang cirinya antara lain: selalu suka "menumpuk dan menimbun" harta/kekayaan untuk kepentingan sendiri bahkan dalam situasi krisis dan kelangkaan, termasuk di dalamnya tindakan memonopoli barang dan atau jasa; senantiasa senang "menghitung-hitung" harta/kekayaan dan untung rugi dari bisnisnya dari perspektif materialistik semata; dan percaya bahwa harta/ kekayaan itu abadi dan mengekalkan sehingga abai terhadap kewajibankewajiban yang harus dibayarkan kepada mereka yang berhak menerimanya. ${ }^{26}$ Ciri lain yang tak kalah pentingnya adalah bahwa kapitalisme yakin terhadap "persaingan bebas" antara dua atau lebih patron melalui cara-cara yang tidak manusiawi dan tidak beradab.

Al-Takathur yang dibenci dan harus dilawan adalah regim yang membuat banyak orang - terutama kaum miskin dan papa - tersungkur, merasakan penderitaan yang mendalam, sampai-sampai banyak di antara mereka menemukan ajal dan terkubur (maqabir, terpinggirkan, termarjinalkan) baik secara sosial, ekonomi, maupun politik. Regim semacam ini merupakan manifestasi dari al-Takathur yang "bego, lengah" atas kesengsaraan dan deprivasi yang dirasakan sebagian besar umat manusia.

Oleh karena itu, sejalan dengan visi keberpihakan dari etos al-Ma'un, spirit al-Takathur yang rasional-bertujuan adalah kapitalisasi yang peduli kepada kemiskinan dan ketertindasan, serta diabdikan untuk membela dan memberdayakan kaum miskin dari kemiskinan karitas, kapasitas dan otoritas mereka, dan bukan semata-mata kapitalisasi untuk melipatgandakan modal itu sendiri. Dengan demikian dapat dipahami bahwa spirit al-Takathur adalah kapitalisasi atau penumpukan modal dalam kerangka filantropi ekonomi, sosial, dan politik. Filantropi ekonomi di sini merujuk pada upaya pengumpulan modal dari berbagai donasi wajib dan sukarela - zakat, infak, sedekah, dan wakaf - yang bertujuan untuk mengembangkan kemandirian, keswadayaan, dan swakelola kehidupan perekonomian kaum miskin dan tertindas, serta meningkatkan ketrampilan hidup dan kapasitas mereka. Filantropi sosial merupakan kapitalisasi dalam kerangka pengentasan kaum mustadh'afin dari marjinalisasi sosial, seperti pengucilan di mana mereka mengalami diskriminasi dan stigma, dan dipaksa untuk terlibat dalam aktivitas ekonomi dan relasi sosial yang memelihara mereka agar tetap miskin. Sedangkan filantropi politik adalah 
upaya kapitalisasi yang bermaksud untuk membebaskan kaum miskin dari marjinalisasi partisipasi, marjinalisasi hak-hak asasi, dan marjinalisasi perlindungan hukum.

Inilah yang dimaksud dengan "spirit keuntungan untuk kebajikan"; "spirit al-Takathur untuk menegakkan pemihakan al-Ma'un". Spirit semacam ini hendaknya tergambar dalam setiap amal usaha dan layanan sosial yang dibangun oleh Muhammadiyah dan komunitas Muslim umumnya. Artinya, sebuah amal usaha dan layanan sosial - baik dalam bidang pendidikan, kesehatan, dan kemaslahatan publik lainnya - bukan berorientasi profit. Lembaga-lembaga ini perlu dikelola dengan manajemen yang baik agar tetap dapat survival dan sustainable, menerapkan subsidi silang dalam hal layanan. Sustainabilitas lembaga ini di samping ditopang dengan pemanfaatan donasi filantropi, juga keuntungan dari layanan yang diberikan. Marjin keuntungan yang diperoleh disisihkan untuk membantu mereka yang kurang beruntung. Dengan cara ini, lembaga-lembaga amal usaha dan layanan sosial tetap bertahan hidup dengan tetap teguh memegang visi pemihakan, pembelaan, dan pemberdayaan kepada kaum miskin. Dengan kata lain, spirit al-Takathur hanya dapat dibenarkan bila ia melandaskan diri pada solidaritas dan keberpihakan al-Ma'un; keuntungan mengabdi kepada kebajikan.

\section{ETOS AL-'ASHR}

Aksi sosial kebudayaan yang dilakukan Kyai Dahlan tentu saja berlandaskan kerangka berpikir dan etos gerakan. KRH. Hadjid, murid termuda $\mathrm{KH}$. Ahmad Dahlan, menulis "7 Falsafah Ajaran dan 17 Kelompok Ayat Alquran" sebagaimana sudah disebutkan pada bagian terdahulu. Menurutnya, Kyai Dahlan mengajarkan surat al-'Ashr kepada murid muridnya lebih dari 7 bulan. Surat al-'Ashr juga diajarkan kepada jamaah Muhammadiyah setiap jam 07.00 pagi, dan kepada jamaah Aisyiyah setiap jam 08.00 pagi. Surat ini juga diajarkan kepada para pemudi setelah zuhur, mereka disuruh menulis dan menghafalkannya. ${ }^{27}$ Menurut Kyai Djazuli, salah seorang guru Madrasah Mu'allimin Muhammadiyah Yogyakarta sejak 1926-an sampai 1956-an, KH. Ahmad Dahlan mengajarkan surat al-'Ashr di mana-mana dan selalu diulang-ulang. ${ }^{28}$ Atas permintaan Nyai Walidah, Kyai Dahlan mengajarkan surat al-'Ashr kepada para buruh perempuan di Kauman. Pengajiannya dinamakan "Pengajian wal-'Ashri". Karena Kyai Ahmad Dahlan suka mengulang-ulang surat al-'Ashr dalam pengajiannya, 
orang-orang Pekalongan masa itu memberi julukan KH. Ahmad Dahlan dengan julukan Kyai Wal-'Ashri. ${ }^{29}$

Selain menyelenggarakan pengajian al-'Ashr, Kyai Dahlan juga mempelopori "Sekolah Kader al-'Ashr" yang dipimpin oleh KRH. Hadjid. Hasil penamaan pendidikan dan pengajaran al-'Ashr ini nampak melekat di hati anak muda Muhammadiyah, dan kemudian lapangan tempat mereka berolahraga bermain sepakbola diberi nama Lapangan Asri. ${ }^{30}$ Sehariharinya lapangan tersebut digunakan oleh Pemuda Muhammadiyah dan latihan PSHW (Persatuan Sepakbola Hizbul Wathan). Pada 1940-an, Lapangan Asri ini dibangun stadion dengan standar lengkap dan tribun berkualitas. Arsiteknya adalah Ir. Suratin salah seorang pendiri dan ketua umum PSII (Persatuan Sepakbola Seluruh Indonesia). ${ }^{31}$ Maksud Kyai Dahlan mengulang-ulang al-'Ashr adalah agar murid-muridnya terbiasa memiliki etos disiplin tepat waktu dan selalu mengisi waktu dengan perbuatan yang bermanfaat (amal salih).

Pertanyaannya mengapa al-'Ashr? Apa pentingnya mengupas al-'Ashr dan kaitannya dengan etos Muhammadiyah? Imam Syafii pernah berkata, andaikan Allah tidak menurunkan ayat atau surat dari Alquran, maka cukuplah dengan wal-'Ashri saja. Surat al-'Ashr itu sangat padat, mencakup kehidupan dan sejarah peradaban umat manusia. Etos al-'Ashr membawa manusia ke arah kehidupan dunia dan akhirat yang berkemajuan dan berperadaban. ${ }^{32}$ Hamka dalam Tafsir al-Azhar menjelaskan bahwa Allah menyebutkan martabat umat manusia itu terdiri empat unsur, yaitu iman, amal shaleh, tausiah kebenaran dan tausiah kesabaran. Jika empat syarat itu tidak terpenuhi, rugilah seluruh masa hidup. ${ }^{33}$ Betapa ayat ini meliputi peradaban dan gerak langkah sejarah manusia. Senada dengan apa yang dikatakan Samuel P. Hutington bahwa hakikat peradaban adalah sejarah manusia, dan sejarah manusia adalah sejarah peradaban itu sendiri. ${ }^{34}$

Dalam surat al-'Ashr terkandung konsep kunci yang menjadi spirit pembangunan peradaban. Ayat-ayat dalam al-'Ashr berbentuk jamak dalam kaitannya dengan peningkatan kualitas hidup individu maupun masyarakat. Kata-kata seperti amanu, 'amilu, dan tawashau, menunjukkan kualitas hidup manusia sebagai kolektifitas (al-muj'tama'). Artinya, al-'Ashr berbicara kehidupan kolektif yang dapat dikaitkan dengan ummah. Muhammadiyah telah lama menggunakan istilah khairu ummah (umat terbaik) sebagai dasar masyarakat utama atau peradaban utama. Masyarakat utama yang berkebudayaan dan berperadaban maju, yang memiliki 
arti berlawanan dengan kata khusr, yakni 'kerugian', 'kehancuran', 'primitif', 'tertinggal', dan 'berkemunduran'. Peradaban utama (berkemajuan) adalah antitesis dari kondisi umum masyarakat khusr (keterbelakangan).

Untuk merajut sejarah peradaban umat manusia dalam dimensi ruang dan waktu, etos al-'Ashr memberikan empat prasyarat. Pertama, iman (alladhina amanu) dapat dimaknai paradigma tauhid sebagai intisari peradaban Islam. Kedua, pelembagaan amal shaleh (wa ‘amilu al-salihah) sebagai kerja-kerja pembangunan peradaban. Ketiga, ilmu pengetahuan, teknologi, dan seni (IPTEKS) sebagai manifestasi dari tawashaw bi al-haqq. Kebenaran, al-haq, dipahami dalam konteks kebenaran relatif, yakni kebenaran IPTEKS yang dapat terus dikembangkan seuai kemajuan zaman. Keempat, moralitas utama yang dipahami dari penggalan tawashaw bi al-shabr. ${ }^{35}$

\section{BERMULA DARI WAKTU}

KRH. Hadjid, murid Kyai Dahlan, menjelaskan makna al-'Ashr sebagai waktu sore atau segala waktu (masa). Ada juga yang menerangkan waktu ashar. Waktu ashar adalah saat banyak orang bermain-main dan menjalankan amal yang buruk. Karena itu, Allah bersumpah dengan wal-'Ashri, artinya waktu ashar itu bukanlah waktu yang rendah dan buruk. Waktu ashar berarti baik atau buruk tergantung cara kita memanfaatkannya. Apabila kita melakukan amal baik, maka pada waktu ashar kita juga mendapatkan kebaikan, karena manusia tidak dikuasai waktu. ${ }^{36}$ Menurut Hadjid, waktu terbagi dua, yaitu permulaan dan akhir. Segala sesuatu pasti berawal dan berakhir. Semua keadaan yang kita alami hari ini adalah buah dari apa yang kita tanam di masa lampau. Jadi ada hukum sebab-akibat. Itulah hakikat kehidupan, ada titik asal mula dan titik akhir. Jadi al-'Ashr adalah hakikat hakikat kehidupan manusia itu sendiri.

Etos al-'Ashr menjadikan gerakan Muhammadiyah tidak hanya memikirkan tentang sepuluh atau dua puluh tahun ke depan. Perubahan seiring berjalan waktu mesti terus terjadi. Karena itu Kyai Dahlan sering menyampaikan peringatan kepada teman temannya supaya waspada terhadap waktu sepanjang hidup:

"Lengah. Kalau sampai terlanjur terus-menerus lengah, tentu akan sengsara di dunia dan akhirat. Maka dari itu jangan sampai lengah, kita harus berhatihati. Sedangkan orang yang mencari kemuliaan di dunia saja, kalau hanya 
seenaknya dan tidak bersungguh-sungguh, tidak akan berhasil, apalagi mencari keselamatan dan kemuliaan di akhirat. Kalau hanya seenaknya sungguh tidak akan berhasil". ${ }^{37}$

Senada dengan itu, Sukriyanto AR memberikan makna wal-'ashri sebagai 'demi waktu yang bergerak ke depan', 'demi waktu yang bergerak maju', 'demi masa yang menuju masa depan', atau 'demi kehidupan yang senantiasa bergerak maju'. ${ }^{38}$ Karena itu, ciri-ciri masyarakat berkemajuan itu visioner, yakni berpikiran maju, berwawasan luas, dan berpandangan jauh ke depan melampaui zaman. Dengan visi tersebut masyarakat berbudaya maju memiliki cirri cirri seperti tepat waktu, tepat janji, kreatif, dinamis, rajin, tertib, kerja keras dan budaya kerjasama antar peradaban.

\section{KONDISI UMUM KEMANUSIAAN}

"Sesungguhnya manusia itu ada di dalam kerugian" mengisyaratkan bahwa secara umum kondisi peradaban umat manusia akan mengalami aneka ragam problem kehidupan (al-khusr). Di masa kelahiran Muhammadiyah, Kyai Dahlan mengambarkan secara umum bahwa umat dan bangsa saat itu belum bersatu hati. Menurutnya, keadaan itu disebabkan oleh tiga hal. Pertama, para pemimpin belum bersatu hati dan saling mengabaikan satu sama lain. Mereka saling bertentangan pendapat disebabkan kurangnya pengetahuan, sehingga menjadikan sempitnya pemikiran. Akibatnya di antara mereka timbul kerusakan (khusr). ${ }^{39}$ Kedua, para pemimpin saat itu belum menunjukan praksis gerakan, dengan tindakan dan perbuatan yang nyata, kebanyakan hanya beretorika belaka bahkan menipu, berbohong, dan perusak (khusr). ${ }^{40}$ Ketiga, kebanyakan para pemimpin dan penguasa saat itu hanya memperhatikan kesejahteraan kaum dan golongan mereka sendiri, bahkan badan maupun perutnya sendiri. ${ }^{41}$

Dengan bersandar pada nasihat al-Ghazali, Kyai Dahlan lalu mengatakan: "Kerusakan rakyat disebabkan kerusakan raja-raja (pemimpinpemimpin negara), kerusakan raja-raja disebabkan oleh kerusakan ulama (karena tidak memberikan nasihat)." Kyai Dahlan melanjutkan, "Apabila pemimpin-pemimpin negara dan para ulama itu baik, maka baiklah alam; dan apabila pemimpin-pemimpin negara dan para ulama itu rusak, maka rusaklah alam dan negara (masyarakat dan negara)" ${ }^{42}$

Akibat globalisasi, perubahan sosial tidak selalu bermakna positif. Kerusakan ekologi, climate change, dehumanisasi, tindak kekerasan (vio- 
lence) atas nama negara, agama, etnis dan begitu seterusnya menjadi tantangan sendiri bagi kelanjutan peradaban Islam. Ulrich Beck menyatakan bahwa tantangan peradaban hari ini adalah munculnya masyarakat berisiko (risk society). ${ }^{43}$ Menurutnya, manusia modern memasuki babak baru dalam modernitas lanjut (late modernity). Kesadaran risiko kemudian mewarnai seluruh proses interaksi sosial, termasuk interaksi politik, ekonomi, budaya dan agama. Jika dalam modernitas klasik masalah sentralnya berkisar pada kekayaan dan bagaimana cara mendistribusikannya secara merata, maka dalam modernitas baru masalah sentralnya adalah risiko dan bagaimana cara mencegah, meminimalkan, atau menyalurkannya. ${ }^{44}$ Tantangannya adalah bagaimana meminimalisir risiko gesekan (clash) antar peradaban, sehingga tidak jatuh ke kubang kehancuran (khusr).

\section{IMAN SEBAGAI FONDASI PERADABAN}

Iman ialah fondasi bangunan peradaban. Menurut Ismail Raji al-Faruqi, tauhid adalah intisari peradaban Islam. Tauhid adalah prinsip penentu pertama dalam kebudayaan dan peradaban. Tauhid memberikan identitas yang mengikat semua unsurnya bersama-sama menjadikan satu kesatuan integral dan organis yang disebut dengan peradaban. ${ }^{45}$

Paradigma tauhid dapat ditemukan dalam definisi Kyai Dahlan tentang agama. Baginya, agama bukan barang yang kasar, yang harus dimasukkan ke dalam telinga. Islam adalah agama fitrah. Artinya ajaran yang sesuai dengan kesucian manusia. Sesungguhnya agama bukanlah amal lahir yang dapat dilihat. Amal yang kelihatan itu hanyalah manifestasi dan daya dari spirit agama. Sesungguhnya agama itu ialah "kecenderungan ruhani untuk menuju kesempurnaan tertinggi yang suci dan luhur, bersih dari pengaruh kebendaan." Manusia religius ialah manusia yang condong kepada kesucian iman kepada Allah, bersih dari pengaruh yang bermacam-macam" ${ }^{46}$

Orang beriman, menurut Kyai Dahlan dengan merujuk pada ayat "wa shaddaqa bil husna", adalah orang yang percaya dengan sungguhsungguh pada perbedaan antara keutamaan dan kenistaan, dan percaya bahwa dirinya, alam semesta, semuanya ada yang mencipta dan memelihara. Tentu, mereka juga percaya bahwa Tuhan akan membalas orang yang beramal salih dan menyiksa yang berbuat kejahatan. Kepercayaan ini benar-benar menghunjam, menera, dan terpatri dalam hati sampai batas-batas menguasai kehendak mereka. Kemudian iman itu berdampak pada amal salih. ${ }^{47}$ 
Karena itu, 'tauhid murni' merupakan pilar pertama 'Islam Berkemajuan'. Tauhid murni akan berimplikasi pada prinsip ketuhanan, seperti Kesatuan penciptaan (unity of creation), kesatuan kemanusiaan (unity of mankind), kesatuan pedoman hidup (unity of guidance), dan kesatuan tujuan hidup (unity of the purpose of life). Tauhid melahirkan etika amal shaleh dimana kemuliaan dan keberhasilan moral manusia dapat dilihat dari bagaimana manusia mengisi ruang dan waktu, untuk memberi manfaat lingkungan sosialnya. Implementasi tauhid dalam pembangunan peradaban ditafsirkan sebagai jalan menuju pencerahan, pembebasan, dan kesemestaan.

\section{PELEMBAGAAN AMAL SHALEH}

Iman tidaklah sempurna tanpa amal shalih. Dalam Tujuh Belas Kelompok Ayat, KRH. Hadjid menjelaskan amal salih adalah amal yang berguna bagi dirinya sendiri, bagi ahli keluarganya, bagi kaum kerabatnya, dan bagi semua manusia yang jauh dari perbuatan kemadlaratan pada seorang kecuali menolak kemudlaratan yang lebih besar, misalkan dakwah mengajak menjalankan kebenaran dan wasiat dengan sabar. ${ }^{48}$ Kyai Dahlan menantang orang-orang yang sering berkoar-koar membela atau berjuang di jalan Allah Swt., dengan kalimat, "Janganlah kamu berteriak-teriak sanggup membela agama, meskipun harus menyumbang nyawa, jiwamu tak usah kamu tawarkan, jika Tuhan mau, tentu akan mati sendiri. Tapi beranikah kamu menawarkan hartamu demi agama? lutlah yang lebih penting saat ini". ${ }^{49}$

Agama Islam berfungsi untuk melakukan transformasi sosial manakala ajaran-ajarannya dapat diterapkan untuk mengatasi masalah-masalah sosial. Gerakan sosial-keagamaan Muhammadiyah merupakan wujud dari fungsionalisasi agama yang didasarkan pertimbangan akal sehat. Secara teologis, hal ini didasarkan pada keterpaduan antara iman dan amal shaleh. Kyai Dahlan tanpaknya merujuk Tafsir Juz Amma surat Al-Ashr tentang iman. Dalam tafsir tersebut dijelaskan yamliku iraadatuhum ('kepercayaan yang sampai menguasai kehendak') sehingga melahirkan amal shaleh yang fundamental. ${ }^{50}$

Karena itu, dalam Muhammadiyah amal shalih bukan semata-mata ritual ibadah mahdhah, tetapi merupakan kerja peradaban yang bermanfaat bagi semesta. Amal shaleh bukanlah eskapisme, ibadah mengasingkan diri dari manusia dan berbagai permasalahan hidup dengan asyik masyuk 
dalam ritual dan dzikir spiritual. Amal shaleh adalah amal yang kreatif dan solutif untuk peradaban. Karena itu supaya amal produktif dan efisien, maka perlu pelembagaan amal shaleh dalam organisasi, bukan individu.

Amal shaleh adalah pembuktian iman. KRH. Hadjid mengutip firman: "lan tanalul birra hatta tunfiqu mimma tuhibbun" (sekali-kali tidak akan (sempurna) suatu kebajikan, sehingga kamu menginfakkan sebagian harta yang sangat kamu cintai'). "Lan tanalul birra, wa yu'tsiruna anfusihim", memberikan barang yang sangat dicintai dan mendahulukan saudara lainnya, mengalahkan dirinya adalah akhlak orang berbuat kebajikan (abrar). ${ }^{51}$ Inilah barangkali yang menjadi etos kemajuan amal usaha Muhammadiyah.

Kini Muhammadiyah berada ditengah-tengah arus putaran globalisasi dalam praxis, bukan globalisasi dalam teori. Globalisasi dan perubahan sosial dalam praktik hidup sehari-hari, harus direspons dengan gerakan amal shaleh. Amal usaha Muhammadiyah harus mulai masuk ke wilayah transportasi, komunikasi, ekonomi, ilmu pengetahuan, teknologi, budaya dan lain-lain.

\section{ETOS DIALOG ANTAR PERADABAN}

Etos dialog antar peradaban merupakan pengembangan tafsir dari tausiah kebenaran dan kesabaran yang memiliki makna transformatif bagi pengembangan IPTEKS dan penguatan moralitas. IPTEKS dan moral menjadi modal utama untuk dialog peradaban. Di era kosmopolitan di mana seluruh manusia menjadi warga dunia (global citizenship), etos dialog antar peradaban sangatlah urgen. Sudah tentu, dalam perjumpaaan antara local dan global citizenship ada pergumulan identitas yang tidak mudah, ada dialektika antara keduanya, antara being a true Muslim dan being a member of global citizenship sekaligus. Ini memerlukan sintesis baru yang dapat memayungi dan menjadi jangkar spiritual bagi mereka yang hidup dalam dunia baru dan dalam arus pusaran perubahan sosial global.

Dalam pidato monumental berjudul "Tali Pengikat Hidup" Kyai Dahlan menyatakan bahwa sesungguhnya manusia berasal dari "satu daging" yang sama. Kemudian ia menyeru kepada umat Islam, "Marilah para pemimpin untuk segera berkumpul membicarakan kebenaran (haq) tanpa memandang dan memilih bangsa. Dan jangan sekali-kali puas dan putusasa sebelum menemukan kebenaran tersebut. Dengan kebenaran yang kita temukan, maka bukankah manusia lalu satu asasnya, satu penget- 
ahuannya, dan satu tindakannya". ${ }^{2}$ Pesan ini mencerminkan etos dialog antar peradaban bahkan etika kemanusiaan universal (etika global). Jika Hans Kung menyuarakan deklarasi etika global dan dialog antar peradaban, maka Kyai Dahlan jauh di awal abad ke-20 sudah menyuarakan kesatuan hati manusia, dan persatuan para pemimpin supaya saling berkumpul dan bermusyawarah. Ini merupakan spirit dialog peradaban yang masih terus relevan dengan kehidupan saat ini.

Kyai Dahlan dan Muhammadiyah terus memelihara sikap kritis dan terbuka terhadap perkembangan IPTEKS, dan keimanannya pada Alquran disertai dengan pemahaman akal yang didasari hati suci. ${ }^{53}$

"Kesempurnaan budi ialah mengerti baik-buruk, benar-salah, kebahagiaan atau penderitaan, dan bertindak atas dasar pengertian itu. Kondisi ini dicapai jika akalnya sempurna, yakni akal kritis dan kreatif bebas yang diperoleh dari belajar. Inti ilmu ini adalah inti ajaran Islam dengan satu asas kebenaran yang memandang manusia berkedudukan sama. Setiap orang wajib menyebarkan ilmu dan Islam ke semua orang di semua tempat. Menjadi guru, sekaligus murid. Belajar dan mengajar untuk kebaikan hidup seluruh umat manusia." 54

Menurut KRH. Hadjid, ada tujuh pertanyaan fundamental yang mesti dijawab: (1) manusia yang tidak mengerti agama dan terus tidak mau belajar mempelajari agama, apakah ini yang benar, atau apakah ini yang salah? (2) Apakah agama yang berbeda-beda satu sama lain itu semua benar? Atau semuanya salah? (3) Apakah sudah mengerti manakah agama yang salah dan mana yang benar? (4) Apakah orang yang menolak agama itu orang yang benar? (5) Apakah agama Hindu, Buddha, Majusi, Shinto, Yahudi, Nasrani itu benar? Ataukah agama Nabi Muhammad (saja yang benar)? (6) Tiap-tiap pemeluk agama mengaku dirinya yang benar, tiaptiap agama mengaku bahwa agamanya itu bersumber dari Allah, maka sekarang kita bertanya, "Apakah tanda-tanda agama Allah itu betul-betul dari Allah?" (7) Selain agama Allah yang benar itu, semua agama-agama itu batal. ${ }^{55}$ Meskipun demikian Muhammadiyah tidak elitis dan eksklusif. Tidak fanatisme menegakkan Islam murni sehingga over reaktif terhadap kelompok lain. Generasi awal Muhammadiyah begitu toleran, kreatifinklusif serta akomodatif, tetapi tidak mempengaruhi prinsip penegakan tauhid murni. 


\section{DARI AL-MA'UN KE AL-'ASHR: DARI ETOS KE SPIRIT PERA- DABAN}

Kyai Ahmad Dahlan telah mengajarkan al-Ma'un dan al-'Ashr. Dua gagasan besar yang meresap kuat dalam alam bawah sadar Muhammadiyah. Dua gagasan itulah yang melandasi visi dan misi gerakan Muhammadiyah hingga kini, yang sudah melewati usia satu abad. Dua surat pendek ini banyak mewarnai kisah Kyai Dahlan dalam mengajarkan alQuran. Tinggal bagaimana selanjutnya dua teologi ini diramu dan dioperasionalisasi menjadi spirit dan etos yang menyatu dengan sistem gerakan Muhammadiyah.

Logika al-Ma'un memiliki logika yang berbeda dari al-'Ashr. Etos alMa'un mengidentifikasi dimensi religius mesti seiring dengan dengan dimensi sosial - kesalihan religius menjadi kurang bermakna jika tidak dibarengi dengan kepedulian sosial. Sementara etos al-'Ashr menarik batas antara dimensi rohani (iman) dan dimensi sosial (amal salih). Bagi al-Ma'un kepedulian sosial merupakan kriteria bagi kesalihan agama, sedangkan bagi al-'Ashr dimensi agama dan dimensi sosial merupakan dua hal yang berbeda—meskipun tidak terpisah—yang masing-masing memiliki kriteria dan ukuran.

Menurut Ahmad Norma Permata, etos al-Ma'un mengajarkan bahwa kepedulian sosial merupakan komponen sekaligus kriteria dari kesalihan spiritual. Dalam bahasa kontemporer, perspektif ini sering diidentikkan dengan ideologi "kiri", yaitu pemahaman strukturalis terhadap ketimpangan sosial yang dilawankan dengan kesetaraan hak individual. Dalam perspektif al-Ma'un, evaluasi moral terhadap ketimpangan sosial menyatakan bahwa peradaban selalu dikuasai kelompok kuat (penguasa, kaya, pandai, dan sebagainya). Karena itu, moralitas al-Maun selalu berpihak kepada kelompok lemah (miskin, tertindas, bodoh, dan lemah). Logika alMa'un melihat para penguasa dan kelompok kaya cenderung sebagai "tersangka" secara moral terkait dengan berbagai penderitaan kelompok lemah dan tertindas. Ini tentu saja berimplikasi secara institusional pada gerakan bernuansa anti kemapanan. ${ }^{56}$

Wawasan al-Ma'un mendorong terbentuknya institusi atau sistem kehidupan yang memberikan peluang kepada kelompok lemah untuk menuntut kesamaan hak dan kesempatan dalam membangun kehidupan. Konsekuensinya akan terbuka kemungkinan benturan-benturan antara kelompok pendatang yang menginginkan perubahan dengan kelompok 
yang ingin mempertahankan kemapanan. Perspektif strukturalis ini secara politis cenderung populis. Di satu sisi, al-Ma'un mengandung logika simplistik bahwa pada dasarnya secara moral manusia mempunyai status setara. Di sisi lain, secara sosial kehidupan manusia terbelah ke dalam tingkatan-tingkatan di mana ada kelompok yang diuntungkan dan dirugikan. Kesimpulannya kelompok yang diuntungkan cenderung dianggap bersalah atau setidaknya bertanggung jawab untuk menolong kelompok yang tertindas. Kelompok lemah dan tertindas biasanya merupakan bagian dari mayoritas.

Logika al-Ma'un yang strukturalis ini juga berkonsekuensi pada strategi membangun kehidupan (peradaban) yang ideal dan berkeadilan. Sebagaimana kelompok strukturalis diberbagai belahan dunia, wawasan al-Ma'un sangat dekat dengan filsafat idealis yang melihat ukuran kebaikan berakar pada sistem yang beroperasi. Sistem yang baik akan menghasilkan realitas kehidupan yang baik; sistem yang buruk akan menghasilkan kehidupan yang buruk. logika al-Ma'un selalu berupaya merumuskan sistem alternatif bagi peradaban Islam. Asumsi dasarnya adalah bahwa problem sosial, ketimpangan dan ketidakadilan lahir dari adanya sistem sosial yang menyimpang dari nilai-nilai ajaran Islam. Maka, untuk memperbaiki keadaan dan menanggulangi ketimpangan, tidak ada cara lain kecuali memperbaiki, atau jika perlu mengganti sistem yang ada.

Sementara logika al-'Ashr mengajarkan bahwa iman dan amal shaleh, meskipun merupakan satu kesatuan yang tidak terpisahkan dari keberislaman, namun keduanya berbeda dalam dimensi dan konstruksinya. Artinya, upaya untuk membangun salah satu di antara keduanya akan secara otomatis membantu dan memfasilitasi perbaikan dimensi yang lain, namun ketiadaan atau kekurangan salah satunya tidak serta merta membatalkan atau mengurangi nilai yang lain. Kepedulian sosial mengandung nilai dan kebaikan agama, namun kebaikan agama tetap dapat dicapai meskipun tanpa kepedulian sosial.

Logika al-'Ashr ini memiliki konsekuensi institusional yang berorientasi pada keterbukaan kesempatan untuk meraih kebaikan, yang mengutamakan kapasitas dan kemampuan usaha individu, apresiasi dan perlindungan hasil kinerja dan prestasi personal. Dalam konteks ini, logika al-'Ashr akan menempatkan peradaban sejalan dengan evaluasi moral. Kebaikan tidak hanya dilihat dari perspektif moral yang pasif melainkan dari ukuran moralitas aktif. Kejayaan dan keberhasilan lebih utama dibanding kekalahan 
dan kegagalan jika posisi moralnya sama. Keberhasilan tidak identik dengan kecurangan sementara kegagalan tidak selalu identik dengan ketulusan. Berbanding terbalik dengan logika al-Ma'un, logika al-'Ashr cenderung melihat penguasa dan orang kaya sebagai teladan untuk diikuti sedangkan kelompok lemah dan tertindas sebagai peringatan dan bahan pelajaran untuk dihindari.

Dalam upaya untuk menyelesaikan persoalan dan memperbaiki situasi, logika al-'Ashr tidak berorientasi pada sistem dan tidak mendorong intervensi atau rekonstruksi sistem-sistem alternatif, melainkan lebih kepada upaya untuk menghilangkan atau mengurangi persoalan dan ketidakadilan yang secara konkret dihadapi oleh masyarakat. Logika al-'Ashr ini dekat dengan tradisi pemikiran "liberal"57 yang rasional dan empiris. Dalam pandangan pengikut kelompok ini, sistem kehidupan merupakan rangkuman dari seluruh proses tindakan dan interaksi usaha seluruh anggota masyarakat. Sistem kehidupan [institusi] bukanlah hasil ciptaan seseorang atau sebuah kelompok, melainkan hasil akhir dari gabungan kehendak dan usaha semua orang. Sistem yang baik dan berkeadlian adalah sistem yang terbuka, yang memberi kesempatan semua orang berpartisipasi dan berkontribusi dalam kehidupan secara setara. Intervensi dan modifikasi terhadap sistem bukanlah sebuah tindakan yang baik karena berarti menempatkan seseorang atau salah satu pihak memiliki posisi lebih tinggi dibanding yang lain.

Selama ini orang lebih melihat Muhammadiyah condong kepada ideologi kiri, karena Kyai Dahlan sangat terinspirasi oleh surat al-Ma'un. Namun, patut dicatat bahwa Kyai Dahlan juga sangat terinspirasi oleh surat al-'Ashr yang memiliki logika institusional berbanding terbalik dengan al-Ma'un. Mungkin sekilas ini terlihat janggal atau bahkan mengada-ada untuk mengatakan bahwa Muhammadiyah sebenarnya mengikuti ideologi liberal. Namun jika dicermati secara metodologis, kita menyaksikan bahwa modus gerakan yang dibangun oleh Kyai Dahlan melalui Muhammadiyah bukanlah dengan cara membangun sebuah sistem alternatif_-baik sistem sosial, politik, maupun ekonomi-melainkan dengan secara langsung menanggulangi persoalan dan ketidakadilan yang secara nyata dihadapi oleh masyarakat.

Kyai Dahlan tidak pernah merumuskan sistem kehidupan yang idealis: apakah sistem sosial harus hierarkis atau egaliter, apakah sistem politik harus demokratis atau teokratis, apakah sistem ekonomi harus bergantung 
atau lepas dari negara. Kyai Dahlan lebih fokus membangun kerja nyata untuk peradaban dalam menanggulangi problem dan ketidakadilan yang ada di masyarakat bai menyangkut kemiskinan, kesehatan, dan pendidikan. Muhammadiyah cenderung terbuka untuk menerima realitas sistem kehidupan yang ada sembari berpikir dan bekerja keras bagaimana menanggulangi persoalan ketidakadilan di masyarakat. Akibatnya, rumusan formal cita-cita institusional (peradaban) Muhammadiyah selalu ambigu: peradaban utama, masyarakat Islam yang sebenar-benarnya-yang sekedar normatif, tanpa acuan indikator, dan bisa ditafsirkan ke mana saja.

Lalu, mana sebenarnya teologi sejati Muhammadiyah: al-Ma'un yang kiri, atau al-'Ashr yang liberal? Banyak orang terbiasa berpikir simplistik, dengan menganggap jika ada dua hal yang berbeda pasti yang satu benar dan yang satu salah. Padahal kemungkinan logisnya tidak hanya itu: karena keduanya bisa sama-sama benar, atau sama-sama salah! Apakah teologi al-Ma'un atau al-'Ashr yang harus diikuti, tidaklah tergantung kepada pilihan dan kehendak bebas, melainkan akan ditentukan oleh konstruk kognitifnya sebagai hasil dari pengalaman institusional yang jalani oleh seseorang: jika dia berada pada situasi yang tidak diuntungkan oleh realitas maka dia akan terdorong mengikuti perspektif dan ajaran al-Ma'un yang melihat realitas secara struktural serta memotivasi untuk mengubah sistem yang ada. Namun jika dia berada pada situasi yang diuntungkan oleh realitas, maka dia akan terdisposisi mengikuti perspektif ajaran al-'Ashr yang menyediakan insentif untuk berfokus pada penyelesaian problem riil yang ada di masyarakat tanpa perlu terlalu mempersoalkan gambar besar sistem yang ada.

Yang perlu digaris bawahi adalah bahwa kedua teologi tersebut dilandaskan pada etos welas asih, dan berujung pada praksis pelembagaan peradaban Muhammadiyah. Muhammadiyah tidak berpretensi untuk condong ke salah satu dari dua ajaran di atas. Jalan tengah di antara keduanya merupakan pilihan terbaik. Bila pada suatu ruang-waktu Muhammadiyah harus condong ke al-Ma'un, itu semua merupakan keniscayaan karena kebutuhan untuk beradaptasi dengan tantangan dan peluang. Demikian juga, kecenderungan ke aras al-'Ashr merupakan respon sesuai dengan dinamika ruang dan waktu.

Ketika gagasan "Islam Transformatif" Moeslim Abdurrahman mencuat ke publik. Dengan spirit al-Ma'un sebagai ruhnya, Kuntowijoyo telah berijtihad untuk melampaui kiri (baca: al-Ma ‘un), dengan menawarkan tran- 
sendensi, di samping liberasi dan humanisasi. Konstruksi IImu Sosial Profetik, yang masih separuh jalan, dipandang masih condong ke kirikirian, karena masih menggunakan kesadaran kritis-strukturalis. Namun setidaknya ijtihadnya sudah mendapatkan satu pahala. Dibutuhkan elaborasi lebih lanjut Islam Profetik agar menjadi jembatan antara al-Ma'un dan al- 'Ashr. Teologi al-Maun telah melahirkan Islam Transformatif, sedangkan al-'Ashr melahirkan Islam Berkemajuan. Keduanya saling membutuhkan. Etika kemanusiaan al-Ma'un harus bergandeng tangan dengan spirit peradaban al-'Ashr, untuk membangun irama dakwah amar ma'ruf nahi mungkar Muhammadiyah.

\section{KESIMPULAN}

Prospek Muhammadiyah sebagai gerakan dan organisasi sosial keagamaan makin cerah sejalan dengan kemampuan melakukan perubahan positif dalam perspektif pemberdayaan ummat. Muhammadiyah tidak perlu terlalu risau dengan soal kemiskinan. Yang dibutuhkan saat ini ialah membangun sistem institusi yang efektif disertai dengan kepemimpinan yang efektif pula. Secara teologis, Muhammadiyah juga perlu terus mereaktualisasi etos al-Ma'un, Muhammadiyah juga memiliki etos al-Ashr untuk pengembangan peradaban. Tidak ada perlawanan selain terhadap ketamakan diri sendiri. Tidak perlu ada kambing hitam untuk dipersalahkan. Meminjam istilah "keadilan" dari Amartya Sen, etos al-Ma 'un ingin membangun keadilan, diawali dengan menolak realitas yang ada. Etos al- 'Ashr hendak menghilangkan ketidakadilan, diawali dengan "menerima realitas yang ada". Muhammadiyah dengan jargon "Islam berkemajuan" memiliki potensi untuk menjadi ideologi peradaban. Bukan hanya slogan teologis-filsafat-paradigmatik, mewujud dalam praxis sosial-politik, sosialekonomi dan sosial-kebudayaan yang nyata. Karena itu, harus ada proyek intelektual yang lebih membumi untuk memberikan kontribusi pada sistem politik ekonomi sosial budaya yang ada. Sebagaimana Kyai Dahlan nyatakan bahwa ilmu itu memiliki nilai guna pragmatis bagi kehidupan manusia. Sebagaimana inspirasi Surat al-Ra 'd: 17

"Allah telah menurunkan air (hujan) dari langit, maka mengalirlah air di lembah-lembah menurut ukurannya, maka arus itu membawa buih yang mengambang. Dan dari apa (logam) yang mereka lebur dalam api untuk membuat perhiasan atau alat-alat, ada (pula) buihnya seperti buih arus itu. Demikianlah Allah membuat perumpamaan (bagi) yang benar dan yang bathil. 
Adapun buih itu, akan hilang sebagai sesuatu yang tak ada harganya; adapun yang memberi manfaat kepada manusia, maka ia tetap di bumi. Demikianlah Allah membuat perumpamaan-perumpamaan."

Di sini tersirat pesan Allah Swt. bahwa hanyalah yang bermanfaat yang akan bertahan di dunia. Ayat ini seakan memberi petunjuk bagi Muhammadiyah, gerakan ini Muhammadiyah harus terus bergerak untuk memberikan manfaat kepada umat manusia dan alam.

Ada empat komponen penting yang perlu ditemukan secara kolektif oleh Muhammadiyah, yaitu: faktor positif di dalam organisasi (Strengths), faktor positif di luar organisasi (Opportunities), faktor aspirasi seluruh organisasi (Aspirations), dan faktor hasil terukur (Results). ${ }^{58}$ Inilah yang menjadi landasan pola pikir untuk perubahan masa depan peradaban yang berkemajuan. Etos berbagi pengalaman, berkolaborasi, terus belajar, dan memberi manfaat menjadi modal utama gerakan Muhammadiyah di abad ke-2.

\section{CATATAN AKHIR}

1 Lihat KRH. Hadjid, Pelajaran KHA Dahlan: 7 Falsafah dan 17 Kelompok Ayat Alquran, Yogyakarta: MPI PPM, 2013, Cet. Ke-5.

2 Baca Kyai Soedja', Islam Berkemajuan: Kisah Perjuangan KH. Ahmad Dahlan dan Muhammadiyah Masa Awal, Jakarta: Al-Wasat, 2009.

3 Naskah Tali Pengikat Hidup Manusia tersebut di atas merupakan transkrip pidato Kyai Dahlan dalam Kongres Tahunan Muhammadiyah pada bulan Desember 1922. Naskah ini kemudian diterbitkan dalam Abdul Munir Mulkhan, Pesan-Pesan Dua Pemimpin Besar Islam Indonesia: Kyai Ahmad Dahlan dan Kyai Hasyim Asy'ari, Yogyakarta: Penerbit Persatuan Yogyakarta, 1986. Naskah tersebut diterbitkan dengan judul The Humanity of Human Life dalam Charles Kurzman (ed.), Modernist Islam 1840-1940: A Sourcebook, Oxford and New York: Oxford University Press, 2002, hlm. 344-348.

4 Baca Abdul Munir Mulkhan, KHA Dahlan dan Muhammadiyah, Yogyakarta: Bumi Aksara, 1990.

5 Abdul Munir Mulkhan, Kiai Ahmad Dahlan, Jejak Pembaruan Sosial dan Kemanusiaan, Jakarta: Kompas, 2010, hlm. 7. "Dalam bidang pendidikan, orang Kristen mendirikan sekolah Penginjil di Jawa tengah (1888). Pada tahun 1905 sekolah tersebut dipindah ke Yogyakarta dan kemudian menjadi sekolah pendeta. Setelah itu, didirikan sekolah-sekolah missi untuk rakyat dan sekolah guru". Lihat Yusron Asrofie, Kyai Haji Ahmad Dahlan Pemikiran dan Kepemimpinannya, Yogyakarta: MPKSDI PPM, 2005, hlm. 23.

6 Menurut riwayat Sukriyanto AR, dulu Muhammadiyah memiliki dua "rumah miskin", satu di Yogyakarta dan Surabaya. Rumah ini menjadi lahan untuk melatih bakat, skill (keahlian) anak muda yang dibekali dengan berbagai 
keterampilan hidup. Wawancara Sukriyanto AR (Rabu, 6 Mei 2015).

7 Dalam bidang sosial, orang Katolik Indonesia mendirikan rumah yatim piatu di Semarang (1809), Jakarta (1856), dan Surabaya (1862). Tahun berikutnya di Padang, Bogor, Magelang dan Malang. Dari pihak Kristen, rumah yatim piatu didirikan di Tegal, Jawa Tengah (1892). Pada awal abad ke-20 Gereja Katolik mendirikan beberapa rumah sakit di kota-kota besar. Lihat: M. Yusron Asrofie, Kyai Haji Ahmad Dahlan dan Kepemimpinannya, Yogyakarta: Offset, 1983, hlm. 22.

8 KRH Hadjid, "Muqaddimah" dalam Budi Setiawan dan Arief Budiman Ch. [Peny.] Pelajaran KHA Dahlan: 7 Falsafah Ajaran dan 17 Kelompok Ayat Alquran, Yogyakarta: LPI PPM, 2006, Cet. Ke-2, hlm. 2-4.

9 Abdul Munir Mulkhan, Warisan Intelektual K.H. Ahmad Dahlan dan Amal Muhammadiyah, Yogyakarta: PT. Percetakan Persatuan, 1990, hlm. 207.

10 Praeadvies Dari Hoofdbestuur Perserikatan Moehammadiyah di Yogjakarta pada Konggres Islam Besar Ceribon, dan Kesatuan Hidup Manusia, terbit pada 1922 dan 1924, dalam Abdul Munir Mukhan, Boeah Fikiran Kijahi H.A. Dachlan, Jakarta, Global Base Review \& STIEAD Press, 2015.

11 Abdul Munir Mukhan, Boeah Fikiran Kijahi H.A. Dachlan..., hlm.16.

12 Lihat: Praeadvies dari Hoofdbestuur Perserikatan Moehammadiyah di Yogjakarta pada "Kongres Islam Besar Cirebon dan Kesatuan Hidup Manusia”, terbit pada 1922 dan 1924 dalam Robert W. Hefner, Sukidi Mulyadi, Abdul Munir Mulkhan, Api Pembaharuan Kiai Ahmad Dahlan, Jakarta: Multi Pressindo, 2008, hlm. 107.

13 Abdul Munir Mulkhan, Kyai Ahmad Dahlan: Jejak Pembaruan..., hlm. 2.

14 Ibid, hlm. 216-217.

15 Lihat: Praeadvies dari Hoofdbestuur Perserikatan Moehammadiyah di Yogjakarta pada "Kongres Islam Besar Cirebon dan Kesatuan Hidup Manusia", terbit pada 1922 dan 1924 dalam Robert W Hefner, Sukidi Mulyadi, Abdul Munir Mulkhan, Api Pembaruan..., hlm. 107.

16 Ibid, hlm. 115.

17 Berawal dari sebuah P.K.U (Penolong Kesengsaraan Umum) Muhammadiyah urusan Balai Kesehatan pada Ahad pagi tanggal 14 September 1924 resmi dibuka di Jl. Sidodadi No. 57 Surabaya. Pada peresmian itu hadir Pengurus Besar Muhammadiyah antara lain: KH. Soedja' dan H. Hadhikusumo dan juga dihadiri Direktur C.B.Z Simpang dr. Tamm. Turut hadir dr. Soetomo dan KH. Mas Mansyur selaku tuan rumah. Di dalam sambutan pidato yang disampaikan oleh dr. Soetomo, beliau dan kawan-kawannya menyatakan kesanggupan untuk memberikan bantuan tenaga kepada PKU Muhammadiyah dalam hal ini Balai Kesehatan dengan sukarela. Dokter-dokter tersebut antara lain: dr. Soetopo, dr. Sardjono, dr. Heerdjan, dr. Soewarno, dr. Soeratman, dr. Soehardjo, dr. Soerjatin, dr. Soekardi, dr. Irsan, dr. Muwaladi, dr. Saleh, dr. Djojohusodo, dr. J.W. Grootings, dr. Aziz, dr. P.H.F. Neynhoff, dr. A.J.F. Tilung dan dr. Rabain. Para dokter tersebut memberikan bantuan tenaga menurut giliran waktu dan keahliannya. Kemudian dr. 
Soedjono lah yang sehari-harinya menjadi dokter tetap di PKU Muhammadiyah sesuai kesepakatan para dokter tersebut. Tak berselang lama setelah pembukaan klinik PKU Muhammadiyah, kira-kira 31,2 bulan setelah berdiri, PKU Muhammadiyah telah memberikan pertolongan pengobatan kira-kira 3.975 orang pasien. Kemudian pada 1925, PKU Muhammadiyah pindah ke gedung yang agak luas di Jl. Karangtembok (Pegirian). Setelah menempati gedung barunya tersebut, PKU Muhammadiyah mendapat kunjungan dari Gubernur Jenderal J.P. van Limburg Stirum. (http:// rsmuhammadiyahjatim.com/rs-pku-mu-hammadiyah-surabaya). Lihat Abdul Munir Mulkhan, Kyai Ahmad Dahlan: Jejak Pembaruan..., hlm. 82.

18 Abdul Munir Mulkhan, Kyai Ahmad Dahlan: Jejak Pembaruan..., hlm. 83-84. Teks asli dikutip dari Bahasa Belanda dikutip dari Suara Muhammadiyah tahun ke-5 Oktober 1924, hlm. 170-171.

19 Sutrisno Kutoyo, Kyai Haji Ahmad Dahlan dan Persyarikatan Muhammadiyah, Jakarta: Balai Pustaka, 1998, hlm. 112-113.

20 KRH. Hadjid, Pelajaran KHA Dahlan..., hlm. 65.

21 Abdul Munir Mulkhan, Kyai Ahmad Dahlan: Jejak Pembaruan Sosial dan Kemanusiaan, Jakarta: Kompas, 2010, hlm. 6.

22 Robert W Hefner, Sukidi Mulyadi, Abdul Munir Mulkhan, Api Pembaruan Kiai Ahmad Dahlan, Jakarta: Multi Pressindo, 2008, hlm. 110.

23 M. Yusron Asrofie, Kiai Haji Ahmad Dahlan: Pemikiran dan Kepemimpinannya, Yogyakarta: Offset, 1983, hlm. 71.

24 Lutfi Effendi, "Tafsir Amali dan Gerakan Kesehatan” http:// suaramuhammadiyah.com/kolom/2016/04/22/tafsir-amali-dan-gerakankesehatan/

25 Quraish Shihab,Tafsir al-Misbah, Jakarta: Lentera Hati, 2002, vol. 15, hlm. 545.

26 QS. Al-Humazah 104:2-3.

27 KRH Hadjid, Pelajaran KHA Dahlan..., hlm. 80.

28 Informasi dari para tokoh Muhammadiyah Pekajangan, Pekalongan pada 1970an. Menurut informasi dari Pimpinan Daerah Muhammadiyah Purworejo, KH Djazuli berasal dari Grabag Purworejo, terakir tinggal di Sangubanyu Kutoarjo. Ia pendiri Poliklinik Muhammadiyah Grabag, di antara juru rawatnya ada yang bernama Sarbini yang kemudian menjadi anggota TNI, pernah menjadi Panglima Divisi Diponegoro, pernah menjadi Menteri Veterang RI di masa Orde Baru. Letjen Sarbini merupakan salah satu inisiator berdirinya Universitas Islam Sultan Agung. Namanya diabadikan menjadi nama Gedung Sarbini di Jakarta. Sukriyanto, AR., "Menangkap Pesan Surat al-Ashr"..., hlm. 5.

29 Ibid., hlm. 6.

30 Ibid.

31 Ibid., hlm. 7.

32 Ibid., hlm. 1.

33 Hamka, Tafsir al-Azhar Juz 28-29-30, Jakarta: Pustaka Panjimas, 1985, hlm. 
256.

34 Baca Samuel Huntington, The Clash of Civilizations and the Remaking of World Order, New York: Simon and Schuster, 1996.

35 M. Abdul Fattah Santoso, dalam”Group Whatsapp Islam Berkemajuan” (23 Maret 2014)

36 KRH. Hadjid. Pelajaran KHA Dahlan, Malang: UMM Press, 2005, hlm. 81.

37 Ibid., 12.

38 Sukriyanto, AR., "Menangkap Pesan Surat al-'Ashr"..., 4.

39 Abdul Munir Mulkhan, Warisan intelektual KH. Ahmad Dahlan dan amal Muhammadiyah, Yogyakarta: Pustaka Persatuan, 1990, hlm. 123-124.

40 Ahmad Dahlan, "Kesatuan Hidup Manusia”, dalam Abdul Munir Mulkhan (peny.), Pemikiran KH Ahmad Dahlan dan Muhammadiyah, Jakarta: Bumi Aksara, 1990, hlm. 8.

41 Ibid.

42 KRH. Hadjid, Pelajaran KHA Dahlan..., hlm. 43.

43 Lihat Ulrich Beck, Risk Society: Toward a New Modernity, London: Sage Publication, 1992.

44 Baca Gabe Mythen, Ulrich Beck A Critical Introduction to the Risk Society, London: Pluto Press, 2004.

45 Isma'il Raji Al-Faruqi, Tauhid, Bandung: Penerbit Pustaka, 1982, hlm. 16.

46 KRH. Hadjid, Pelajaran KHA Dahlan..., hlm. 26.

47 Ibid., hlm. 86.

48 Ibid.

49 Junus Salam, Riwayat Hidup KHA. Dahlan: Amal dan Perjuangannya, Jakarta: Depot Pengadjaran Muhammadijah, 1968, hlm. 51.

50 Achmadi, Merajut Pemikiran Cerdas Muhammadiyah: Perspektif Sejarah, Yogyakarta, Suara Muhammadiyah: 2010, hlm. 25.

51 KRH. Hadjid, Pelajaran KHA Dahlan..., hlm. 163.

52 Ibid., hlm. 10.

53 Abdul Munir Mulkhan, Menggugat Muhammadiyah, Yogyakarta: Pajar Pustaka Baru, 2000, hlm. 43-44.

54 Robert W. Hefner, Sukidi Mulyadi, dan Abdul Munir Mulkhan, Api Pembaruan Kiai Ahmad Dahlan, Jakarta: Multi Pressindo, 2008, hlm. 25.

55 KRH. Hadjid, Pelajaran KHA Dahlan..., 107.

56 Ahmad Norma-Permata, "Teologi Al-'Ashr dan Visi Peradaban Muhammadiyah” dalam Azaki Khoirudin, Teologi Al-Ashr: Etos dan Ajaran KHA Dahlan yang Terlupakan, Yogyakarta: Suara Muhammadiyah, 2015.

57 Meskipun sebenarnya istilah liberal dan istilah kiri sama-sama bersifat konotatif, yang tidak deskriptif melainkan evaluatif, namun istilah kiri cenderung berkonotasi positif sementara istilah liberal cenderung berkonotasi negatif. Penamaan peradaban liberal, atau yang mungkin lebih banal lagi peradaban kapitalis, adalah istilah yang digunakan atau yang berasal dari kelompok yang tidak suka terhadap sistem tersebut. Sementara para pendukungnya lebih suka menggunakan istilah liberal secara politis atau pilihan publik (public choice) 
secara metodologis. Ahmad Norma-Permata, "Teologi Al-'Ashr dan Visi Peradaban Muhammadiyah”.

58 Lihat David L. Cooperrider, Diana Whitney, Jacqueline M. Stavros, Appreciative Inquiry Handbook for Leaders of Change, Crown Custom Publishing Inc., 2nd Edition, 2008.

\section{DAFTAR PUSTAKA}

Achmadi. 2010. Merajut Pemikiran Cerdas Muhammadiyah: Perspektif Sejarah, Yogyakarta, Suara Muhammadiyah.

Asrofie, M. Yusron. 1983. Kyai Haji Ahmad Dahlan dan Kepemimpinannya, Yogyakarta: Offset.

Asrofie, M. Yusron. 2005. Kyai Haji Ahmad Dahlan Pemikiran dan Kepemimpinannya, Yogyakarta: MPKSDI PPM.

Beck, Ulrich. 1992. Risk Society: Toward a New Modernity, London: Sage Publication.

Cooperrider, David. L, Diana Whitney, Jacqueline M. Stavros. 2008. Appreciative Inquiry Handbook for Leaders of Change, Crown Custom Publishing Inc.

Dahlan, Ahmad. 1990. "Kesatuan Hidup Manusia”. Dalam Abdul Munir Mulkhan (peny.), Pemikiran KH Ahmad Dahlan dan Muhammadiyah. Jakarta: Bumi Aksara

Dahlan, KHA. 2002. The Humanity of Human Life dalam Charles Kurzman (ed.), Modernist Islam 1840-1940: A Sourcebook, Oxford and New York: Oxford University Press, hlm. 344-348.

Effendi, Lutfi. "Tafsir Amali dan Gerakan Kesehatan”, http:// suaramuhammadiyah.com/kolom/2016/04/22/tafsir-amali-dan-gerakankesehatan/

Al-Faruqi, Isma'il Raji. 1982. Tauhid, Bandung: Penerbit Pustaka.

Hadjid, KRH. 2005. Pelajaran KHA Dahlan, Malang: UMM Press.

Hadjid, KRH. 2006. "Muqaddimah". Dalam Budi Setiawan dan Arief Budiman Ch. [ed.]. Pelajaran KHA Dahlan: 7 Falsafah Ajaran dan 17 Kelompok Ayat Alquran. Yogyakarta: LPI PPM.

Hadjid, KRH. 2013. Pelajaran KHA Dahlan: 7 Falsafah dan 17 Kelompok Ayat Alquran, Yogyakarta: MPI PPM.

Hamka. 1985. Tafsir al-Azhar Juz 28-29-30, Jakarta: Pustaka Panjimas.

Hefner, Robert W., Sukidi Mulyadi, Abdul Munir Mulkhan. 2008. Api pembaharuan Kiai Ahmad Dahlan, Jakarta: Multi Pressindo.

Huntington, Samuel. 1996. The Clash of Civilizations and the Remaking of World Order, New York: Simon and Schuster.

Kutoyo, Sutrisno. 1998. Kyai Haji Ahmad Dahlan dan Persyarikatan Muhammadiyah, Jakarta: Balai Pustaka.

Mukhan, Abdul Munir. 2015. Boeah Fikiran Kijahi H.A. Dachlan, Jakarta, Global Base Review \& STIEAD Press.

Mulkhan, Abdul Munir. 2010. Kiai Ahmad Dahlan, Jejak Pembaruan Sosial dan Kemanusiaan, Jakarta: Kompas. 
Mulkhan, Abdul Munir. 1986. Pesan-Pesan Dua Pemimpin Besar Islam Indonesia: Kyai Ahmad Dahlan dan Kyai Hasyim Asy'ari, Yogyakarta: Penerbit Persatuan Yogyakarta.

Mulkhan, Abdul Munir. 1990. Warisan Intelektual K.H. Ahmad Dahlan dan Amal Muhammadiyah, Yogyakarta: PT. Percetakan Persatuan.

Mulkhan, Abdul Munir. 1990. Warisan intelektual KH. Ahmad Dahlan dan amal Muhammadiyah, Yogyakarta: Pustaka Persatuan.

Mulkhan, Abdul Munir. 2000. Menggugat Muhammadiyah, Yogyakarta: Pajar Pustaka Baru.

Mulkhan, Abdul Munir. 2010. Kyai Ahmad Dahlan: Jejak Pembaruan Sosial dan Kemanusiaan, Jakarta: Kompas.

Mulkhan, Abdul Munir.1990. KHA Dahlan dan Muhammadiyah, Yogyakarta: Bumi Aksara,

Mythen, Gabe. 2004. Ulrich Beck A Critical Introduction to the Risk Society, London: Pluto Press

Permata, Ahmad Norma. 2015. "Teologi Al-Ashr dan Visi Peradaban Muhammadiyah”. Dalam Azaki Khoirudin. Teologi Al-Ashr: Etos dan Ajaran KHA Dahlan yang Terlupakan, Yogyakarta: Suara Muhammadiyah.

Salam, Junus. 1968. Riwayat Hidup KHA. Dahlan: Amal dan Perjuangannya, Jakarta: Depot Pengadjaran Muhammadijah.

Shihab, Quraish. 2002. Tafsir al-Misbah, Jakarta: Lentera Hati

Soedja', Kyai. 2009. Islam Berkemajuan: Kisah Perjuangan KH. Ahmad Dahlan dan Muhammadiyah Masa Awal, Jakarta: Al-Wasat.

Wawancara Sukriyanto AR (Rabu, 6 Mei 2015). 